\title{
Characterization of an ATP-dependent DNA ligase from the acidophilic archaeon "Ferroplasma acidarmanus" Fer1
}

\author{
Brian R. Jackson · Catherine Noble • \\ Manuel Lavesa-Curto · Philip L. Bond · \\ Richard P. Bowater
}

Received: 12 July 2006/ Accepted: 17 October 2006/Published online: 30 November 2006

(C) Springer 2006

\begin{abstract}
Analysis of the genome of "Ferroplasma acidarmanus" Fer1, an archaeon that is an extreme acidophile, identified an open reading frame encoding a putative ATP-dependent DNA ligase, which we termed FaLig. The deduced amino acid sequence of FaLig contains 595 amino acids, with a predicted molecular mass of $67.8 \mathrm{kDa}$. "F. acidarmanus" Fer1 is classified as a Euryarchaeote, but phylogenetic analysis using amino acid sequences showed that FaLig is more similar to DNA ligases from Crenarchaeota, suggesting that lateral transfer of these genes has occurred among archaea. The gene sequence encoding FaLig was cloned into a bacterial expression vector harbouring an upstream His-tag to aid purification. Conditions for expression and purification from Escherichia coli were identified and recombinant FaLig was confirmed to be an ATP-dependent DNA ligase. Optimal conditions for nick-joining by the protein were $\mathrm{pH} 6-7,0.5 \mathrm{mM}$ ATP, in the presence of either $\mathrm{Mg}^{2+}$ or $\mathrm{Mn}^{2+}$. Using a range of nicked, double-stranded nucleic acids, ligation was detected with the same substrates as previously determined for other DNA ligases. Although FaLig is
\end{abstract}

Communicated by G. Antranikian.

B. R. Jackson - M. Lavesa-Curto · R. P. Bowater $(\bowtie)$

School of Biological Sciences, University of East Anglia,

Norwich NR4 7TJ, UK

e-mail: r.bowater@uea.ac.uk

C. Noble

Department of Biochemistry, University of Leicester,

Leicester LE1 9HN, UK

P. L. Bond

Advanced Wastewater Management Centre,

University of Queensland, Brisbane, QLD 4072, Australia the DNA ligase from one of the most extreme acidophilic organism yet studied, this characterization suggests that its biochemical mechanism is analogous to that of enzymes from other cellular systems.

Keywords DNA ligase - Ferroplasma acidarmanus . DNA nick-joining · Acidophilic · Archaea
Abbreviations
DTT Dithiothreitol
FaLig "Ferroplasma acidarmanus" Fer1 DNA ligase
IPTG Isopropyl $\beta$-D-1-thiogalactopyranoside
LB Luria-Bertani broth
T4Dnl T4 DNA ligase

\section{Introduction}

"Ferroplasma acidarmanus" Fer1 (hereafter referred to as F. acidarmanus Fer1) is an acidophilic archaeon, which was first identified as a dominant prokaryote in the acid-drainage biofilm at Iron Mountain in Northern California (Dopson et al. 2004; Edwards et al. 2000; Golyshina and Timmis 2005; Tyson et al. 2004). F. acidarmanus Fer1 is mesophilic, with optimal growth at about $40^{\circ} \mathrm{C}$, but it survives in extremely acidic conditions, with optimal growth at $\mathrm{pH}$ 1.2. This group of Archaea plays important roles in geochemical iron and sulphur cycles and has also been implicated as a major contributor in the process of acid mine drainage, which causes considerable environmental damage by the release of metal-rich acidic effluents into groundwater (Dopson et al. 2004; Edwards et al. 2000; Golyshina and Timmis 2005; Schleper et al. 2005). Coupling these points with its unusual microbiology, identification of 
factors involved in the metabolism of $F$. acidarmanus Fer1 holds considerable interest for both applied and basic sciences.

The two major phyla of the Archaea, the Crenarchaeota and the Euryarchaeota, both contain organisms that inhabit low $\mathrm{pH}$ environments (Makarova and Koonin 2003; Makarova and Koonin 2005; Schleper et al. 2005). The only family of cultured acidophiles among the Crenarchaeota are the Sulfolobaceae, which grow at pH 2-4 (Makarova and Koonin 2003; Makarova and Koonin 2005; She et al. 2001). The Euryarchaeota contains several members that grow at extremely low $\mathrm{pH}$, including $F$. acidarmanus Fer1 and the other identified member of this family, $F$. acidiphilum (Edwards et al. 2000; Golyshina and Timmis 2005). The Ferroplasmaceae lie within the order of Thermoplasmatales, which also contains the other characterized acidophiles, the Thermoplasmaceae and Picrophilaceae (Darland et al. 1970; Futterer et al. 2004; Golyshina et al. 2006; Golyshina and Timmis 2005). The Thermoplasmatales are able to grow at very low $\mathrm{pH}$, typically $<\mathrm{pH} 2$, with Picrophilus torridus and $F$. acidarmanus Fer1 being the most extreme with growth observed at $\mathrm{pH} 0$ (Dopson et al. 2004; Futterer et al. 2004). However, all of these organisms are believed to maintain an intracellular $\mathrm{pH}$ of around 5 (Golyshina et al. 2006; Golyshina and Timmis 2005; Macalady et al. 2004; Searcy 1976). Thus, the cytoplasmic conditions of these organisms are distinct from their environment, which is aided by the fact that their single cytoplasmic membrane has low permeability to protons (Golyshina et al. 2006; Golyshina and Timmis 2005). It would, therefore, be expected that the proteins of these organisms have optimal activity close to the mildly-acidic cytoplasmic $\mathrm{pH}$, as supported by characterization of a novel DNA repair protein encoded by $F$. acidarmanus Fer1 (Kanugula et al. 2005). By contrast, a recent study identified that several intracellular or membrane-bound proteins of $F$. acidiphilum had optimal activity in the $\mathrm{pH}$ range 2-4 (Golyshina et al. 2006). It is not yet clear how this observation relates to the environment within the cell and its impact upon cell metabolism. However, if the cytoplasm of the archaeon experiences acidity levels of $\mathrm{pH} 2$, even briefly, then it is likely that extensive DNA damage would be induced, with a concomitant effect on DNA metabolism.

DNA ligases are a class of proteins that are involved in many aspects of DNA metabolism. These enzymes act to join breaks in the backbone of DNA and are essential for all cellular organisms due to the requirement for completion of replication, but they also participate in the repair and recombination of DNA
(Doherty and Suh 2000; Shuman and Lima 2004; Tomkinson et al. 2006; Wilkinson et al. 2001). All nucleotidyl transferases are believed to operate through similar biochemical mechanisms consisting of three separate steps (Doherty and Suh 2000; Lehman 1974; Shuman and Lima 2004; Timson et al. 2000; Wilkinson et al. 2001). For DNA ligases the first step involves the enzyme attacking the $\alpha$-phosphate of the nucleotide cosubstrate to form a covalent enzyme-adenylate (AMP) intermediate. For the Archaea, the AMP moiety is generally provided by ATP (EC 6.5.1.1), while the essential DNA ligases of bacteria obtain this from $\mathrm{NAD}^{+}$(EC 6.5.1.2) (Wilkinson et al. 2001). High resolution structures of several DNA ligases confirm that they exhibit a modular structure, with the common core required for adenylation linked to other domains that bind substrate (Doherty and Suh 2000; Shuman and Lima 2004; Tomkinson et al. 2006).

The first archaeal DNA ligase was identified in 1992 from a hyperthermophilic Crenarchaeon, Delsulfurolobus ambivalens, with the amino acid sequence of this protein being most similar to those of Eukaryotic viral and cellular ATP-dependent ligases (Kletzin 1992; Nakatani et al. 2000). This is not particularly surprising since Archaea have been shown to be similar to Eukarya in many aspects of DNA metabolism, despite their morphological and structural resemblance to Bacteria (Kelman and White 2005; White 2003). Generally, the putative DNA ligases of Archaea are of fairly uniform size and their primary structures are extensively conserved. Despite this overall similarity, DNA ligases from Crenarchaeota and Euryarchaeota differ in the sequence of motif $\mathrm{V}$ as well as in the spacing between some motifs (Lai et al. 2002) (also see Fig. 1b).

More recently, recombinant versions of DNA ligases have been characterized from a number of archaea that grow at high temperature or salinity. The observation of some unexpected characteristics provides increasing interest in this class of proteins. For example, ATP-dependent DNA ligases from Thermococcus kodakaraensis (Nakatani et al. 2000) and $T$. fumicolans (Rolland et al. 2004) are also able to use $\mathrm{NAD}^{+}$as the cofactor for ligation. The ability for DNA ligases to use both ATP or NAD ${ }^{+}$as a cofactor appears to be specific to DNA ligases from Thermococcales, an order of hyperthermophilic microorganisms that belongs to the Euryarchaeota (Rolland et al. 2004). The relationship between ATP- and $\mathrm{NAD}^{+}$-dependent DNA ligases has taken a further twist upon analysis of Haloferax volcanii, since this organism encodes both types of protein that share the essential DNA-joining functions (Zhao et al. 2006). 

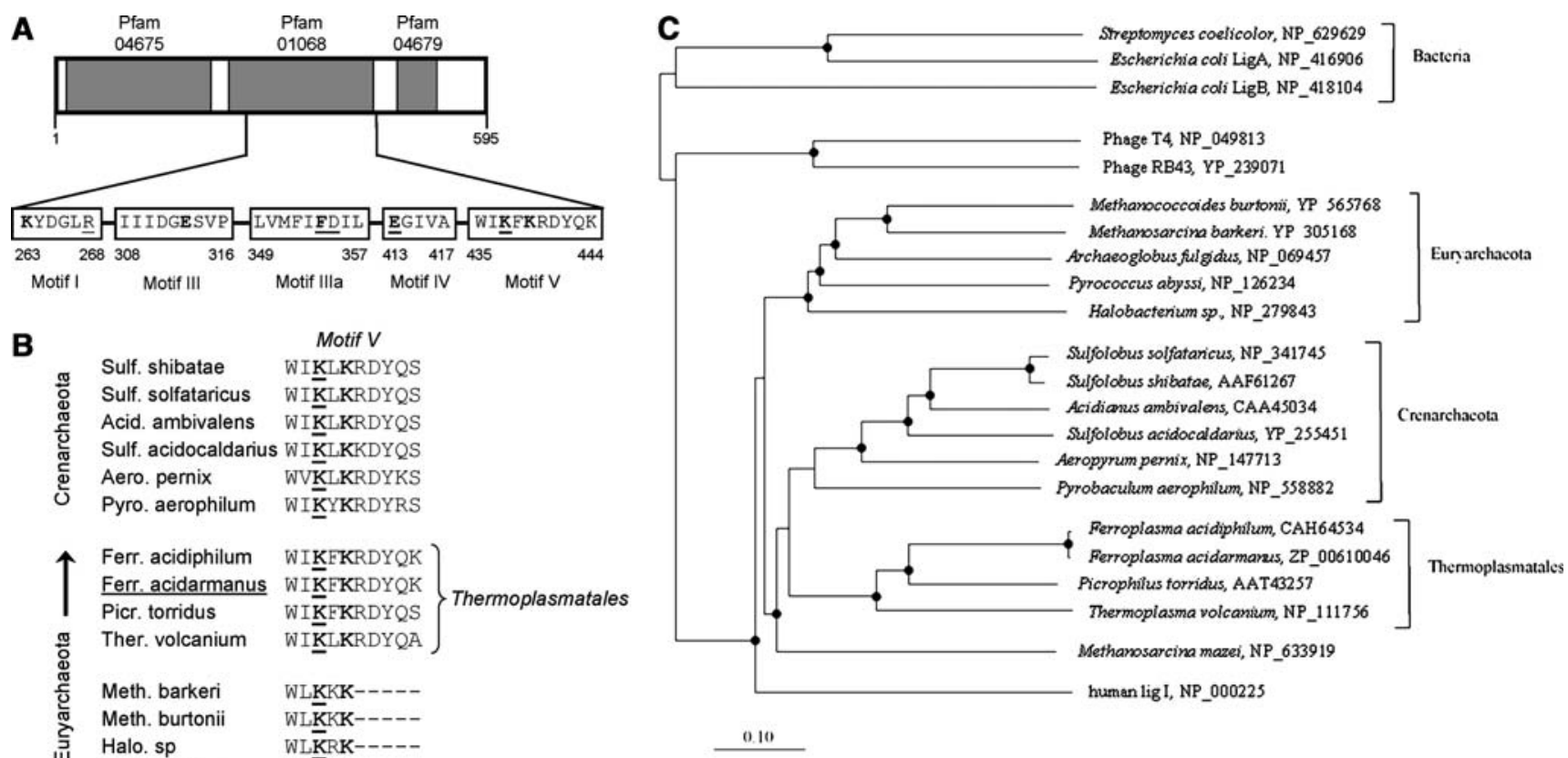

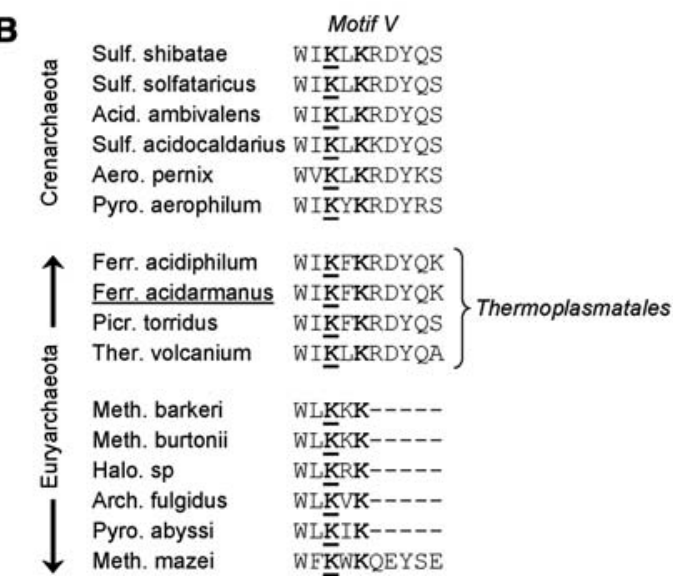

Fig. 1 Ferroplasma acidarmanus DNA ligase. Standard singleletter abbreviations indicate specific amino acids. Residues in bold are conserved components of the active site (Shuman and Lima 2004), whilst those underlined are identical to those conserved in bacterial ATP-dependent DNA ligases (Wilkinson et al. 2001). a Schematic diagram of conserved domains within the putative DNA ligase from Ferroplasma acidarmanus Fer1. All numbers refer to the position of the amino acid within the total protein of 595 amino acids. The position of five motifs conserved within ATP-dependent DNA ligases is indicated. Sections marked in grey and the Pfam names directly above them highlight significant similarity to domains within the conserved domain database (CDD) (Marchler-Bauer et al. 2005). Pfam04675 relates to a conserved $\mathrm{N}$-terminal region among ATP-dependent DNA ligases; Pfam01068 relates to a conserved catalytic

To extend analysis of this essential class of enzymes even further, we have evaluated the DNA ligase from $F$. acidarmanus Fer1, the most extreme acidophile yet studied. We characterized a recombinant version of the DNA ligase by analysing the in vitro nick-joining activity of the enzyme using a variety of doublestranded nucleic acids. The biochemical properties of the recombinant protein were similar to previously described ATP-dependent DNA ligases, though optimal activity was obtained at $\mathrm{pH} 6-7$, close to the measured intracellular $\mathrm{pH}$ of the organism.

\section{Material and methods}

\section{Growth of bacterial cultures}

Details of bacterial strains and host plasmids used for cloning and protein expression have been described (adenylation) domain of DNA ligases; Pfam04679 relates to a conserved C-terminal region among ATP-dependent DNA ligases. b Alignment of motif V identified for DNA ligases from a variety of archaea. Fuller names of organisms are provided in (c). Complete sequences and organism names are available at the NCBI database (http://www.ncbi.nlm.nih.gov/). c Evolutionary distance dendogram of DNA ligase amino acid sequences estimated by neighbour-joining as described in the Materials and methods. The bacterial NAD ${ }^{+}$-dependent ligase sequences, from $S$. coelicolor and E. coli, were used as the out-group. Branch points supported by the maximum-likelihood estimations are indicated by filled circles. Evolutionary distances are indicated by the sum of horizontal branch lengths and the scale bar represents changes per amino acid. Protein sequence accession numbers are included in the tree

previously (Lavesa-Curto et al. 2004; Wilkinson et al. 2003; Wilkinson et al. 2005). Growth of E. coli was performed at a variety of temperatures on plates and in liquid cultures. In all cases, Luria broth (LB) was the nutrient media. Antibiotics were added to media as required, with final concentrations of ampicillin at $100 \mu \mathrm{g} \mathrm{ml}^{-1}$ and kanamycin at $50 \mu \mathrm{g} \mathrm{ml}^{-1}$. Stock cultures containing $25 \%$ glycerol were stored at $-80^{\circ} \mathrm{C}$ and used to streak on to fresh LB-agar plates as required. Bacterial cells were made chemically competent for DNA transformation and stored in $200 \mu \mathrm{l}$ aliquots at $-80^{\circ} \mathrm{C}$ (Sambrook and Russell 2001).

Bioinformatic analyses

The genome sequence of $F$. acidarmanus Fer1 was obtained from http://www.genome.jgi-psf.org/draft microbes/ferac/ferac.home.html. BLAST analysis was 
performed upon sequences contained within the NCBI database (http://www.ncbi.nlm.nih.gov/). For phylogenetic analysis the DNA ligase amino acid sequences were managed using ARB, a software environment for sequence data (Ludwig et al. 2004). Multiple sequence alignments were performed using ClustalW. Evolutionary distance and tree topology was estimated using the neighbour-joining method and this was repeated by the maximum likelihood method using Dayhoff's model and star decomposition.

\section{Cloning of Ferroplasma acidarmanus \\ Fer 1 DNA ligase}

Cloning of the predicted DNA ligase from $F$. acidarmanus Fer1 was performed following the strategies employed for bacterial DNA ligases described previously (Lavesa-Curto et al. 2004; Wilkinson et al. 2003; Wilkinson et al. 2005). The gene was amplified by PCR with a proof-reading DNA polymerase from genomic DNA using the following primers:

"Forward primer": 5'-CAT ATG ACA AAA TCT TAT AAT ATA CTA TAT G-3'.

"Reverse primer": 5'-GGA TCC TTA TTT TGT TTT TTT CTG CAT TTT ATA AAG-3'.

Proteins were over-expressed from pET-16b (Novagen) and contained a $10-$ His tag within 21 additional amino acids $(2.5 \mathrm{kDa})$ at the $\mathrm{N}$-terminus. To allow over-expression of proteins in E. coli GR501, the fulllength gene plus the His-tag were excised from pET$16 \mathrm{~b}$ vectors using the $N c o$ I and $B a m H I$ sites and cloned into pTRC99A (Amersham Pharmacia), as described previously (Lavesa-Curto et al. 2004; Wilkinson et al. 2003; Wilkinson et al. 2005).

\section{Protein purification}

For protein expression, all E. coli cultures were grown in LB containing ampicillin and kanamycin. Initial experiments identified that over-expressed FaLig was highly insoluble in E. coli. The amount of soluble protein was not increased despite testing a wide range of growth conditions, including temperatures from 16 $37^{\circ} \mathrm{C}$, slower rates of shaking, different concentrations of IPTG, cold- and heat-shock, and strains encoding extra copies of tRNA genes that are rare in E. coli (data not shown). Some soluble FaLig was obtained when the pET16b derivatives were transformed into $E$. coli BL21 (DE3) harbouring pOFX-bad-KJ1, which expresses the E. coli chaperone proteins DnaK and DnaJ under the control of the pBAD promoter (Castanie et al. 1997). After transformation, cells were plated on LB-agar containing antibiotics and grown overnight at $37^{\circ} \mathrm{C}$. Single colonies were inoculated into $10 \mathrm{ml}$ liquid media, grown overnight at $37^{\circ} \mathrm{C}$ and diluted 100-fold into fresh media $(1 \mathrm{l})$. After growth at $25^{\circ} \mathrm{C}$ to mid $\log$ phase $\left(\mathrm{OD}_{600}=0.5\right)$, expression of chaperones from pOFX-bad-KJ1 was induced by addition of $0.2 \%$ L-arabinose and expression of FaLig was induced by addition of IPTG to $0.4 \mathrm{mM}$. After incubation at $25^{\circ} \mathrm{C}$ for $20 \mathrm{~h}$, cells were harvested, sonicated and centrifuged to separate soluble and insoluble fractions. Proteins were purified from the soluble fraction using columns with affinity for the Histag (Novagen His•Bind ${ }^{\circledR}$ ). Fractions containing the purified protein were confirmed by SDS-PAGE, pooled together in volumes of $2.5 \mathrm{ml}$ and the buffer was exchanged using disposable PD-10 desalting columns (Amersham Biosciences, UK), with the proteins being eluted in $20 \mathrm{mM}$ Tris, $\mathrm{pH} 7.5,200 \mathrm{mM} \mathrm{NaCl}$. Protein concentrations within cell extracts were determined by the Bradford method (Bio-Rad Protein Assay). Since low amounts of FaLig were obtained, the amount of purified FaLig was estimated from comparison with known amounts of bovine serum albumin after electrophoresis and silver staining of SDS-PAGE (Sambrook and Russell 2001). In general, $40 \mu \mathrm{g}$ of FaLig was obtained from each litre of induced culture. For long-term storage at $-80^{\circ} \mathrm{C}$, glycerol was added to a final concentration of $25 \%(\mathrm{v} / \mathrm{v})$.

\section{Analysis of ligation activity}

In vitro assays of ligation activity were performed using the nicked, 40 bp DNA described previously (LavesaCurto et al. 2004; Wilkinson et al. 2003; Wilkinson et al. 2005). Additional experiments assessed the activity of FaLig with a variety of nicked, 20 bp RNA:DNA hybrids (Bullard and Bowater 2006). Oligonucleotides were purchased from MWG-Biotech, Germany. The nicked 40-bp substrates were used in end-point and time-course assays of the in vitro ligation activity. The buffer used for standard reactions was $100 \mathrm{mM}$ Trisacetate, $\mathrm{pH} 6.5,20 \mathrm{mM} \mathrm{MgCl}_{2}, 20 \mathrm{mM}$ DTT, $2 \mathrm{mM}$ ATP. End-point reactions were performed as follows: 0.66-1.28 pmoles ligase, 22.5 pmol oligonucleotide substrate in a total volume of $10 \mu \mathrm{l}$. The reaction mix was incubated at $30^{\circ} \mathrm{C}$ for $18 \mathrm{~h}$ then stopped using $10 \mu \mathrm{l}$ formamide stop solution (Sambrook and Russell 2001). The effect of $\mathrm{pH}$ on the extent of ligation was examined by performing assays in reaction buffer as indicated above except that it contained Tris-acetate ( $\mathrm{pH} 4-7$ ) or Tris- $\mathrm{HCl}$ ( $\mathrm{pH} 7-9$ ); measurements of the $\mathrm{pH}$ of all solutions were performed at $20^{\circ} \mathrm{C}$. Timecourse reactions were performed as follows: $17.9 \mathrm{pmol}$ ligase, 315 pmoles oligonucleotide substrate in a total 
volume of $140 \mu$ l. The reaction mix was incubated at $30^{\circ} \mathrm{C}$, with $10 \mu \mathrm{l}$ aliquots being removed at various time points and added to $10 \mu \mathrm{l}$ formamide stop solution. Reactions were also performed with a variety of nucleotides and divalent metals at the described concentrations in $100 \mathrm{mM}$ Tris-acetate, $\mathrm{pH} 6.5,20 \mathrm{mM}$ DTT. In many reactions, the extent of ligation by T4 DNA ligase was compared using optimal amounts as identified previously (Bullard and Bowater 2006).

At the end of all ligation experiments, samples were heated in a $95^{\circ} \mathrm{C}$ heating block for $5 \mathrm{~min}$ and analysed on a $15 \%$ polyacrylamide-urea gel $(8.3 \times 6.2 \mathrm{~cm})$ in $0.5 \times$ TBE. Reaction products on the gel were visualized using a Bio-Rad Molecular Imager FX. Quantitation was performed using the public domain NIH Image/J program (available at http://www.rsb.info.nih.gov/nih-image/). For time-course experiments, the extent of ligation was expressed as mole of ligated product per mole of ligase per minute of reaction time. The initial rates of reactions were measured from the extent of ligation in the linear section of the plotted data.

To assay for ligation activity in vivo, we used E. coli GR501, which has a temperature-sensitive mutation in ligA (Dermody et al. 1979; Lavesa-Curto et al. 2004). Cells were transformed with $\mathrm{p} \operatorname{Tr} 999 \mathrm{~A}$ containing falig downstream of an inducible promoter. To assist production of soluble FaLig, pOFX-bad-KJ1 was also transformed into the cells and the chaperone proteins DnaK and DnaJ were induced by addition of $0.2 \%$ L-arabinose (Castanie et al. 1997). Following strategies described previously (Lavesa-Curto et al. 2004), growth was assessed at 30 and $>43^{\circ} \mathrm{C}$.

\section{Results}

Identification of an ATP-dependent DNA ligase within the genome of Ferroplasma acidarmanus Fer1

Ferroplasma acidarmanus Fer1 has a genome of $1.8 \mathrm{Mbp}$, which is $73 \% \mathrm{~A}+\mathrm{T}$ base-pairs and encodes 1,713 candidate proteins (see http://www.genome.jgipsf.org/draft_microbes/ferac/ferac.home.html). Annotation of the genome identified a homologue of an ATP-dependent DNA ligase (EC 6.5.1.1) encoded by gene 542 (NCBI accession number ZP_00610046). This is the only open reading frame in $F$. acidarmanus Fer1 predicted to be a functional DNA ligase so, for convenience, we refer to this gene as falig and its protein product as FaLig. Three regions of the predicted amino acid sequence have significant similarity to domains within the Conserved Domain Database (CDD) (Marchler-Bauer et al. 2005) (Fig. 1a). Each of these domains is found in other DNA ligases, as indicated by their Pfam nomenclature (Finn et al. 2006): Pfam04675 relates to a conserved $\mathrm{N}$-terminal region present in many, but not all, ATP-dependent DNA ligases; Pfam01068 relates to the conserved catalytic (adenylation) domain of DNA ligases; Pfam04679 relates to a conserved C-terminal region present in many, but not all, ATP-dependent DNA ligases. Interestingly, BLAST analysis of FaLig at the NCBI database identified that eukaryotic sequences have relatively high similarity to FaLig. Among these, the closest homologs, at approximately $30 \%$ identity, were several types of mammalian DNA ligase I, which participate in DNA replication.

Along with RNA ligases and mRNA capping enzymes, DNA ligases form a group of enzymes known as covalent nucleotidyl transferases. These enzymes are defined by the essential lysine residue situated within motif I, the first of a series of conserved colinear motifs (Doherty and Suh 2000; Shuman and Lima 2004; Tomkinson et al. 2006). Closer examination of the sequences within the motifs of FaLig confirmed that it contains all amino acids that are essential for the function of nucleotidyl transferases (Shuman and Lima 2004) and all amino acids that are highly conserved in predicted bacterial ATP-dependent DNA ligases (Wilkinson et al. 2001) (Fig. 1a). Previous analysis suggests that enzymes from Crenarchaea are homologues of Eukaryotic DNA ligase I, whilst the versions from Euryarchaea are more similar to ATP-dependent enzymes from some Viruses (Lai et al. 2002). Interestingly, motif $\mathrm{V}$ of DNA ligases from the Thermoplasmatales, which includes FaLig, are more similar to DNA ligases from Crenarchaeota compared to those from Euryarchaeota (Fig. 1b). This relationship is supported by phylogenetic analysis of the complete DNA ligase sequences (Fig. 1c). ATP-dependent DNA ligases and the classical bacterial $\mathrm{NAD}^{+}$-dependent enzymes are distant in evolutionary terms (Nakatani et al. 2000). Thus, the amino acid sequences of the NAD ${ }^{+}$-dependent DNA ligases from E. coli and Streptomyces coelicolor (Wilkinson et al. 2003) were used as an out-group to improve confidence in the phylogenetic description. To allow comparison with ATP-dependent DNA ligases from other organisms, sequences from human DNA ligase I and bacteriophages T4 and RB43 were also included. In agreement with an earlier, more-detailed phylogenetic description (Nakatani et al. 2000), our analysis confirms that all archaeal ATP-dependent DNA ligases have a closer evolutionary relationship to each other than to other 
ATP-dependent DNA ligases. In addition, our analysis shows that Thermoplasmatales are grouped in a clade that is separated from the other Euryarchaeota but branches with the Crenarchaeota (Fig. 1c). This is not congruent with the general evolutionary relationship of the Thermoplasmatales that places these organisms in the Euryarchaeota (Dopson et al. 2004; Ruepp et al. 2000). However, the tree topology was supported by both the neighbour-joining and the maximum likelihood analyses and suggests lateral gene transfer has occurred during the evolution of the DNA ligase genes of the Euryarchaeota.

In summary, bioinformatic and phylogenetic analysis of the predicted sequence of FaLig suggests that it is likely to be an ATP-dependent DNA ligase that has characteristics of the Eukaryotic class of enzymes that participate in DNA replication.

Purification of FaLig and confirmation of ATP-dependent DNA ligase activity

No detailed experimental analysis of a DNA ligase from such an extreme acidophile has yet been reported, so it is unclear if such a hostile environment affects the biochemical activity of these enzymes. To allow biochemical assessment of the activity of this class of enzymes, we wished to determine the ability of a recombinant form of FaLig to join nicks in doublestranded nucleic acids. The gene for FaLig was cloned into the bacterial expression vector pET-16b, overexpressed and purified by affinity chromatography to an in-frame N-terminal His-tag, as has been used in studies of a number of different nucleic acid ligases (Ho and Shuman 2002; Ho et al. 2004; Lavesa-Curto et al. 2004; Nandakumar et al. 2004; Nandakumar and Shuman 2004; Wilkinson et al. 2003; Wilkinson et al. 2005; Yin et al. 2003; Yin et al. 2004). Including the addition of the His-tag from pET-16b, the total molecular weight of FaLig is $70.3 \mathrm{kDa}$. Preliminary expression analysis of FaLig induced in several derivatives of E. coli BL21 identified that it was almost totally insoluble (data not shown). Since the gene has $61 \% \mathrm{~A}+\mathrm{T}$ base pairs it is rather atypical for E. coli, and the use of some unusual codons may lead to problems with folding that could be a factor in producing insoluble protein. Solubility of proteins was improved by growth at $25^{\circ} \mathrm{C}$ and inclusion of plasmids expressing $E$. coli chaperonins (Castanie et al. 1997), but it was possible to obtain only relatively small amounts of FaLig; in the experiments reported here the concentration of His-tagged FaLig was approximately $12 \mu \mathrm{g} /$ ml. Analysis on SDS-PAGE showed the final sample contained a number of polypeptides (Fig. 2), as is
A

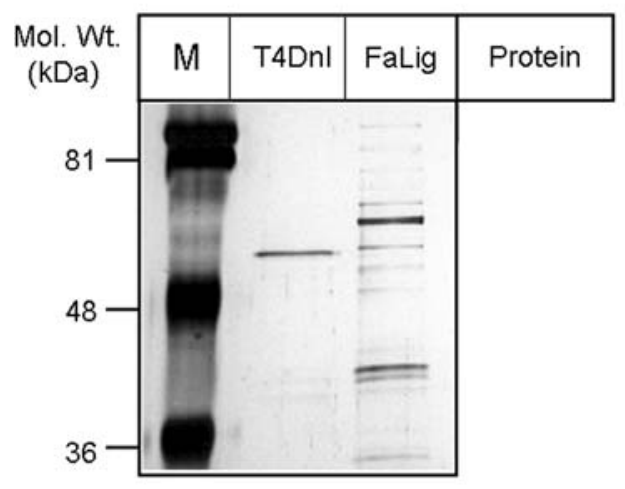

B

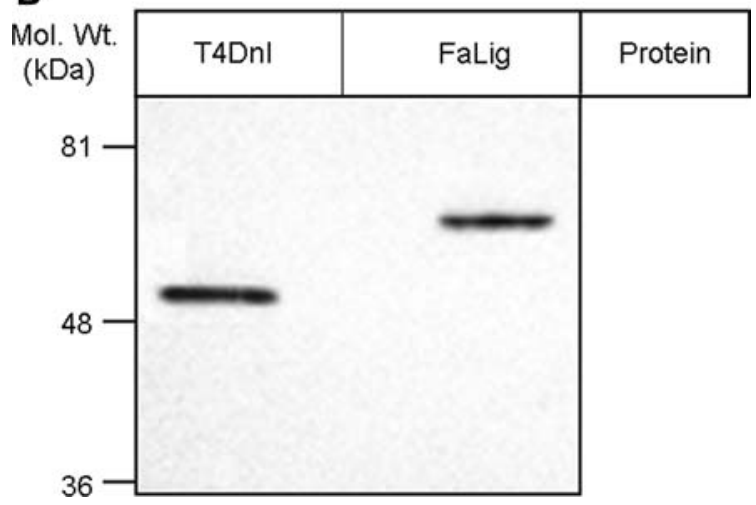

Fig. 2 Purified recombinant Ferroplasma acidarmanus DNA ligase. SDS-PAGE analysis of FaLig and T4Dnl used during this study. Purified proteins were analyzed by electrophoresis on a 10\% SDS-polyacrylamide gel. Proteins were identified by silver staining (a) or western blot using a monoclonal antibody to the His-tag (b). Molecular weights refer to proteins contained in a marker included on the same gel

typical for samples prepared using the assistance of induced chaperonins (Castanie et al. 1997; Chen et al. 2003; Goenka and Rao 2001). Western blot analysis using an antibody to E. coli LigA (Lavesa-Curto et al. 2004) did not detect the presence of this $\mathrm{NAD}^{+}$dependent DNA ligase in the preparation of FaLig (data not shown).

The standard biochemical assay of nucleic acid ligation activity uses denaturing gel electrophoresis to detect increases in length of an oligonucleotide upon ligation. The nick-joining activity of FaLig was assessed using the substrate described previously (Lavesa-Curto et al. 2004; Wilkinson et al. 2003; Wilkinson et al. 2005), consisting of a 40-bp double-stranded oligonucleotide containing a gap between bases 18 and 19 of one strand. In all experiments we compared the activity of FaLig with a recombinant form of the ATP-dependent DNA ligase from bacteriophage T4 (T4Dnl), which has been well characterized as being efficient in joining nicks in this substrate (Bullard and Bowater 
2006). Preliminary experiments confirmed that FaLig harboured ATP-dependent DNA ligase activity under conditions that are used for T4 DNA ligase obtained from commercial sources, i.e. pH 7.5, 1 mM ATP (data not shown).

From this confirmation that FaLig is a DNA ligase, it is to be expected that it will join nicks that occur during replication-since it is the only DNA ligase encoded within its genome. To assess this function of the protein, we expressed the recombinant protein in E. coli GR501. This strain contains a temperaturesensitive mutation in chromosomal-encoded $E$. coli LigA (Dermody et al. 1979), which prevents growth on LB-agar plates at temperatures of $42{ }^{\circ} \mathrm{C}$ and above. Use of this strain in complementation experiments with a plasmid-expressed DNA ligase has proved useful for analysis of in vivo activity of a variety of DNA ligases, including human DNA ligase I, which is ATPdependent (Kodama et al. 1991; Lavesa-Curto et al. 2004; Wilkinson et al. 2003, 2005). To assist production of soluble FaLig in E. coli GR501, the chaperone proteins DnaK and DnaJ were also induced from pOFX-bad-KJ1 (Castanie et al. 1997). Induction of the chaperone proteins allowed slight growth of $E$. coli GR501 on LB-agar plates, even up to $45^{\circ} \mathrm{C}$, though the extent of growth was much reduced compared to strains expressing wild-type E. coli LigA. Overexpression of FaLig in E. coli GR501 allowed more vigorous growth of the host compared to over-expression of proteins without DNA ligase activity (data not shown). This observation is consistent with FaLig being able to seal nicks produced during replication of DNA in E. coli.

\section{Biochemical characterization of nick-joining by FaLig}

The most remarkable aspect of the physiology of $F$. acidarmanus Fer1 is its ability to grow at very low $\mathrm{pH}$. Therefore, to assess whether $\mathrm{pH}$ might be an important influence on its ability to ligate DNA, we characterized the activity of FaLig and T4Dnl across a range of $\mathrm{pH}$. Experiments were performed at $30^{\circ} \mathrm{C}$ from $\mathrm{pH} 4-9$ using two different buffers (Ho and Shuman 2002; Ho et al. 2004; Yin et al. 2003): experiments at pH 4-7 were performed with Tris-acetate (Fig. 3a) and pH 7-9 were performed with Tris-HCl (Fig. 3b). All other components of the reaction were unchanged. Note that ligation was only detected in reactions containing buffer, cations and ATP and could not, therefore, be provided by residual $\mathrm{NAD}^{+}$-dependent $\mathrm{DNA}$ ligase from the $E$. coli cell extract. Quantitation of the extent of ligation identified that T4Dnl had optimal nick- joining activity at $\mathrm{pH} 7-8$, in broad agreement with that identified previously for T4Dnl (Bullard and Bowater, 2006). By contrast, for FaLig optimal nick-joining activity was observed at pH 6-7 (Fig. 3c).

The majority of archaeal DNA ligases that have been experimentally analysed use ATP as the co-factor for ligation, although those from some Euryarchaeota can also use other nucleotides (Jeon and Ishikawa 2003; Nakatani et al. 2000; Rolland et al. 2004; Zhao et al. 2006). To assess the situation with FaLig, we analysed nick-joining in the presence of a variety of cofactors (Fig. 4a). Ligation was only observed in the presence of ATP or, to a lesser extent, dATP. The lack of ligation in the presence of $\mathrm{NAD}^{+}$confirmed that the nick-joining activity was not due to the DNA ligase encoded on the E. coli chromosome. The concentration of the nucleotides used in the reaction was varied to provide a more detailed analysis of co-factor utilization (Fig. 4b). This experiment showed that optimal activity was obtained at concentrations equal and greater than $0.5 \mathrm{mM}$ ATP; no inhibition of activity was observed up to $4 \mathrm{mM}$ ATP. This analysis demonstrated that the maximal activity of FaLig in the presence of dATP was about 50 times less compared to that obtained with ATP. We also determined the nick-joining activity in the presence of a variety of cations (Fig. 5). Using the standard buffer conditions for FaLig, efficient nick-joining was observed in the presence of $\mathrm{Mg}^{2+}$ and $\mathrm{Mn}^{2+}$, but no ligation was detected in the presence of $\mathrm{Ca}^{2+}, \mathrm{Cu}^{2+}, \mathrm{Co}^{2+}, \mathrm{Ni}^{2+}$ or $\mathrm{Zn}^{2+}$.

To allow further comparison with previously studied DNA ligases, the rate of nick-joining by FaLig was determined. The extent of ligation at $30{ }^{\circ} \mathrm{C}$ was analysed at various times (Fig. 6a). The amount of ligation at each time-point was quantitated and the initial rates of nick-joining were determined for FaLig and T4Dnl under the same conditions (Fig. 6b). For FaLig, the extent of nick-joining increased linearly during a period of $2 \mathrm{~h}$, giving a rate during this period of approximately 0.2 ligation events $\mathrm{min}^{-1}$. The reaction with $\mathrm{T} 4$ Dnl occurred faster, with a maximal rate of approximately 2 ligation events $\mathrm{min}^{-1}$ during the initial $10 \mathrm{~min}$. Thus, FaLig joins nicks in dsDNA approximately 10 times less efficiently than T4Dnl.

Recent studies identify that DNA ligases may join breaks in a variety of double-stranded nucleic acids (Martins and Shuman 2004; Pascal et al. 2004; Sekiguchi and Shuman 1997; Sriskanda and Shuman 1998; Tomkinson et al. 2006), with the range of active substrates varying compared to enzymes characterized as "RNA" ligases (Bullard and Bowater 2006). To assess how FaLig fitted into these categories, we analysed its nick-joining activity on a range of substrates. Each of 

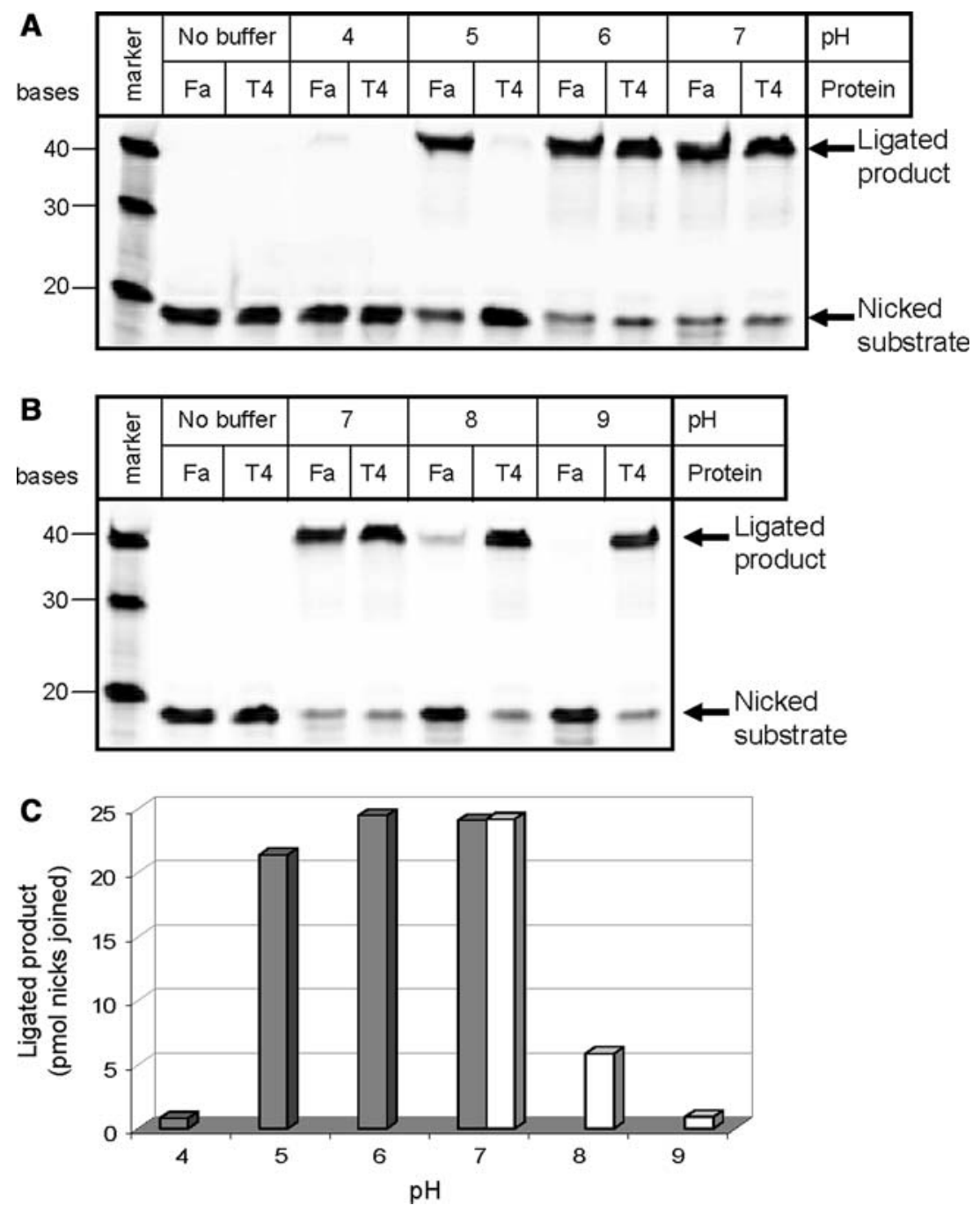

Fig. 3 Effect of $\mathrm{pH}$ on the nick-joining activity of Ferroplasma acidarmanus DNA ligase. Nicked 40-bp substrates were used in assays of the in vitro ligation activity of DNA ligase from $F$. acidarmanus Fer1 (FaLig) and bacteriophage T4 (T4Dnl) at various $\mathrm{pH}$. The buffer for reactions was $100 \mathrm{mM}$ Tris-acetate or

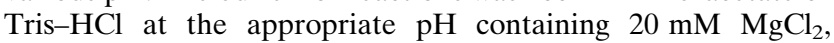
$20 \mathrm{mM}$ DTT and $2 \mathrm{mM}$ ATP. Reactions were performed in $10 \mu \mathrm{l}$ for $18 \mathrm{~h}$ at $30^{\circ} \mathrm{C}$ with $1.28 \mathrm{pmol}$ of FaLig or 1 pmol of T4Dnl. Samples were analysed on a denaturing polyacrylamide gel. The

the three individual strands used in substrate preparation was used as ribo- or deoxyribonucleotides. Appropriate mixing of each strand produced eight different combinations of double-stranded, nicked nucleic acids (Fig. 7a). These consisted of DNA only (substrate 1), RNA only (substrate 2) and a variety of DNA:RNA hybrids (substrates 3-8). End-point ligation analysis identified that FaLig was able to join the nicks in substrate 1 (dsDNA) most efficiently and that it also had significant activity with substrate 7 , which has RNA as the donor of the 3'-OH at the nick (Fig. 7b). The same range of substrates was ligated by marker contained a mixture of fluorescein-labelled oligonucleotides of the specified size. The lanes referred to as "No buffer" are negative controls to assess the effect of buffer constituents and contained only protein, DNA and water. a Buffer used for all reactions contained Tris-acetate at $\mathrm{pH} 4-7$. b Buffer used for all reactions contained Tris- $\mathrm{HCl}$ at $\mathrm{pH}$ 7-9. c Quantitation of extent of ligation by FaLig. Experiments performed with Trisacetate and Tris- $\mathrm{HCl}$ are shown by the grey and white bars, respectively

T4Dnl (Bullard and Bowater 2006), thus confirming that FaLig is effectively a functional "DNA" ligase.

\section{Discussion}

Due to their fundamental role during replication, DNA ligases are likely to have been required within the earliest cells. Although there are two types of enzyme that use different co-factors during ligation and there are distinct versions in the different kingdoms of life, it is clear that all DNA ligases harbour similar "core" 

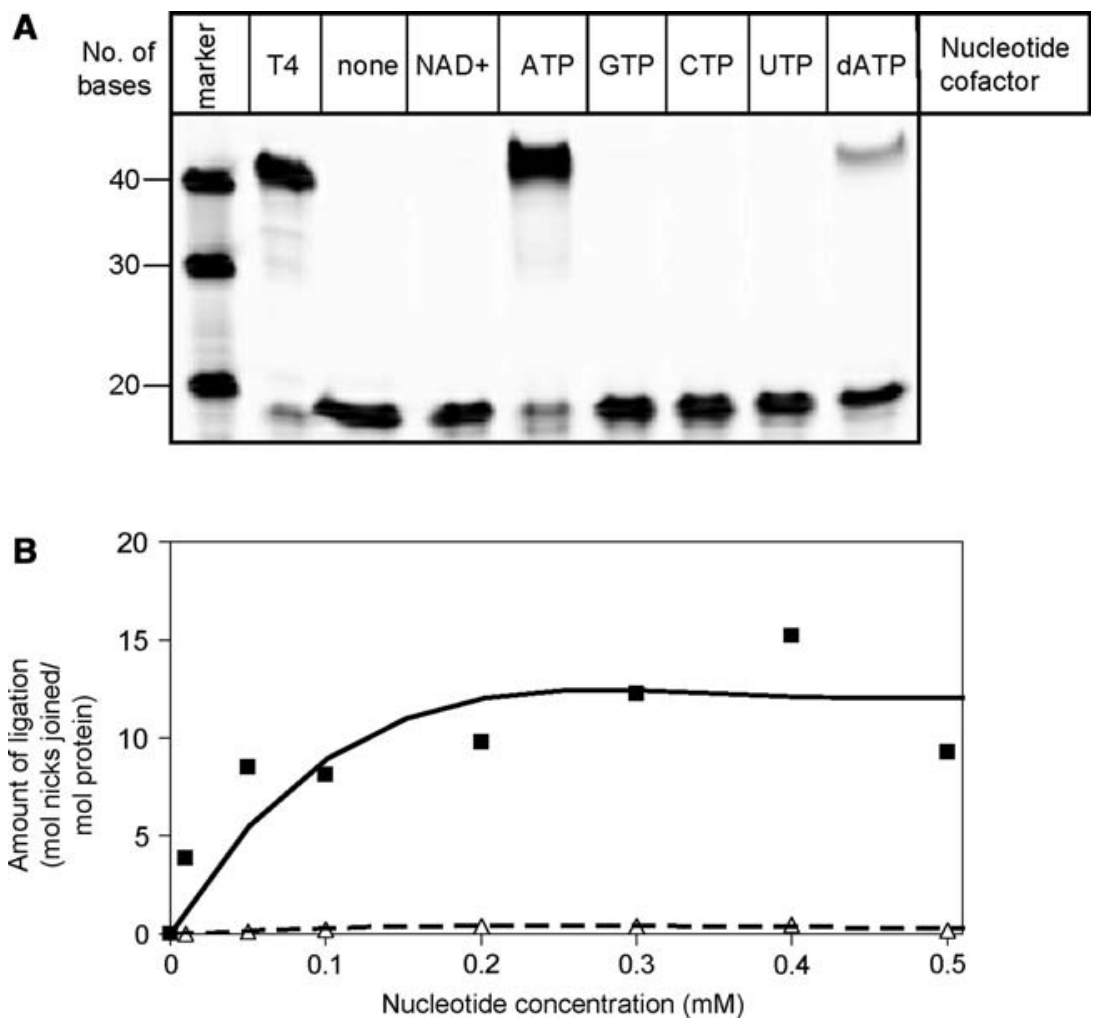

Fig. 4 Co-factor requirements for the nick-joining activity of Ferroplasma acidarmanus DNA ligase. Nicked 40-bp substrates were used to assess the effect of nucleotide on in vitro ligation activity of $F$. acidarmanus Fer1 DNA ligase (FaLig). a Reactions were performed in a total volume of $10 \mu \mathrm{l}(100 \mathrm{mM}$ Tris-acetate, $\mathrm{pH} 6.5,20 \mathrm{mM} \mathrm{MgCl}, 20 \mathrm{mM}$ DTT) for $18 \mathrm{~h}$ at $30^{\circ} \mathrm{C}$ with $1.28 \mathrm{pmol}$ of FaLig using the specified co-factor at $2 \mathrm{mM}$, or $52 \mu \mathrm{M}$ for $\mathrm{NAD}^{+}$. All samples were analysed on a denaturing

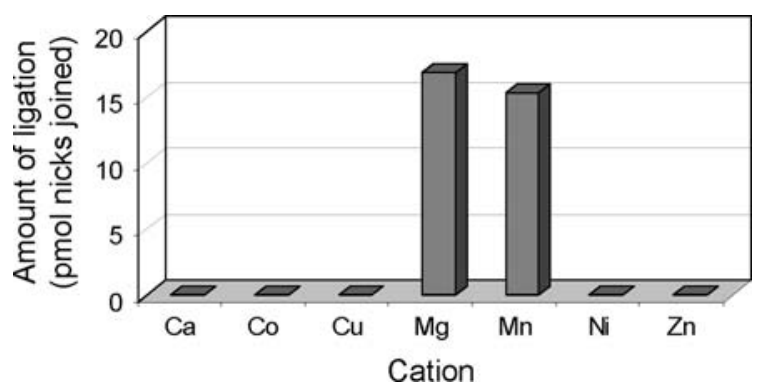

Fig. 5 Cation requirements for the nick-joining activity of Ferroplasma acidarmanus DNA ligase. Nicked 40-bp substrates were used to analyse the effect of cation on the in vitro ligation activity of $F$. acidarmanus Fer1 DNA ligase (FaLig). Reactions were performed in a total volume of $10 \mu \mathrm{l}(100 \mathrm{mM}$ Tris-acetate, $\mathrm{pH} 6.5,20 \mathrm{mM}$ DTT, $2 \mathrm{mM}$ ATP) for $18 \mathrm{~h}$ at $30^{\circ} \mathrm{C}$ with 1.28 pmol of FaLig using the specified cation at $10 \mathrm{mM}$. After analysis on a denaturing polyacrylamide gel, the extent of nickjoining was quantitated

features (Shuman and Lima 2004; Tomkinson et al. 2006; Wilkinson et al. 2001). Recently, however, characterization of DNA ligases from some archaea have polyacrylamide gel. The marker contained a mixture of fluorescein-labelled oligonucleotides of the specified size. b Reactions were performed in a total volume of $10 \mu \mathrm{l}$ for $18 \mathrm{~h}$ at $30^{\circ} \mathrm{C}$ with $1.28 \mathrm{pmol}$ of FaLig using various concentrations of ATP (filled squares) or dATP (open triangles). The extent of ligation in each sample was quantitated from analysis of the samples on a denaturing polyacrylamide gel. The lines represent an approximate best fit through the data points

identified unexpected features, particularly in relation to the role of the co-factor in enzyme function (Jeon and Ishikawa 2003; Nakatani et al. 2000; Rolland et al. 2004; Zhao et al. 2006). We have cloned and characterized the single DNA ligase encoded by the genome of $F$. acidarmanus Fer1, an archaeon that is viable at extremely acidic conditions.

Bioinformatic analysis of the gene sequence suggested that gene 542 (falig) of the $F$. acidarmanus Fer1 genome would be an ATP-dependent DNA ligase and our in vitro biochemical studies using recombinant protein confirmed this to be the case. The bioinformatic analysis suggests that FaLig is likely to exhibit a modular three-dimensional structure, closely related to those obtained for other DNA ligases (Doherty and Suh 2000; Shuman and Lima 2004; Timson et al. 2000; Tomkinson et al. 2006). We observed that FaLig favoured $\mathrm{Mg}^{2+}$ over other divalent cations, though significant activity was retained with $\mathrm{Mn}^{2+}$. FaLig was also able to join nicks between a ribonucleotide containing 
A
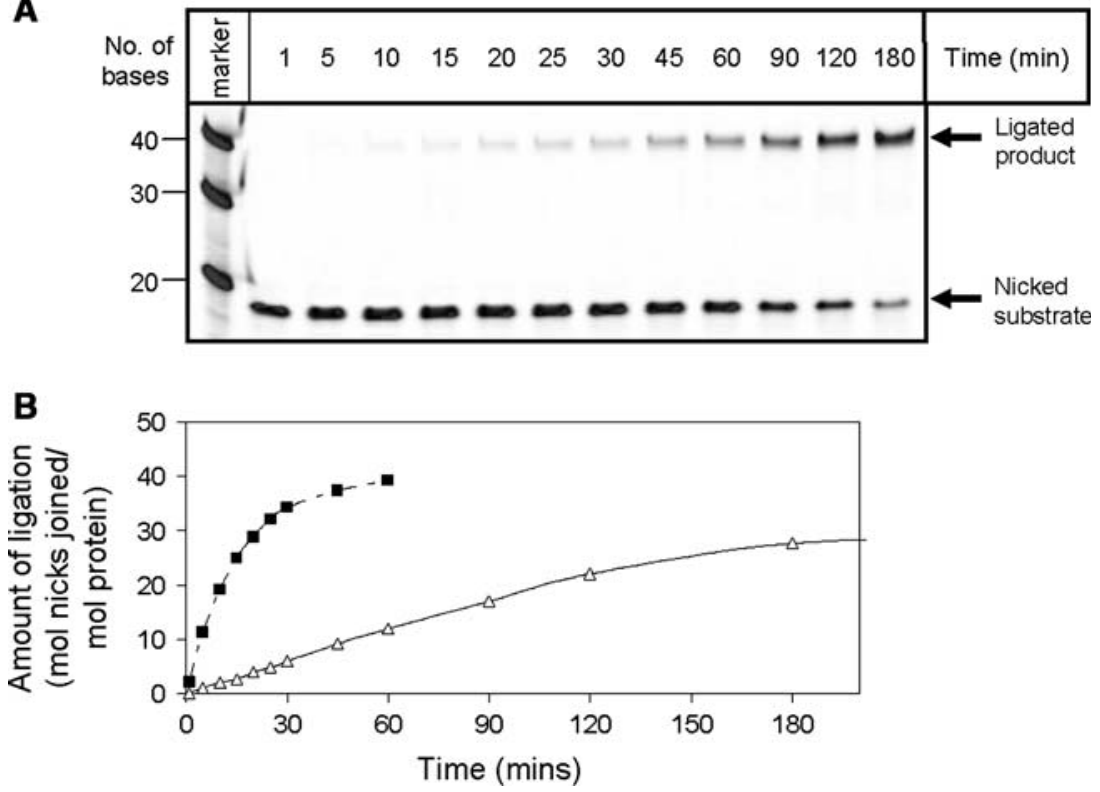

Fig. 6 Time-course analysis of the nick-joining activity of Ferroplasma acidarmanus DNA ligase. Nicked 40-bp substrates were used to determine the rates of in vitro ligation activity of DNA ligase from $F$. acidarmanus Fer1 (FaLig) and bacteriophage T4 (T4Dnl). a Representative reaction performed with FaLig for various times at $30^{\circ} \mathrm{C}$. Reactions contained $315 \mathrm{pmol}$ of substrate and $18 \mathrm{pmol}$ of FaLig in a total volume of $140 \mu \mathrm{l}$. At

the $3^{\prime}$-hydroxyl and deoxyribonucleotide containing the $5^{\prime}$-phosphate. These effects on biochemical activity have been observed for other nucleic acid ligases, including human DNA ligase I (Pascal et al. 2004), the bacterial cellular enzyme DraRnl from Deinococcus radiodurans (Martins and Shuman 2004) and viral enzymes Chlorella PBCV-1 DNA ligase (Sriskanda and Shuman 1998), Vaccinia DNA ligase (Sekiguchi and Shuman 1997) and T4 RNA ligase 2 (Nandakumar et al. 2004; Nandakumar and Shuman 2004; Nandakumar and Shuman 2005).

In most facets that we examined, FaLig was observed to be a rather typical ATP-dependent DNA ligase. This is not particularly surprising since it is the only DNA ligase encoded within the genome and it must, therefore, act in fundamental metabolic pathways, such as joining nicks at Okazaki fragments. As might be expected from such cellular requirements, FaLig has high levels of homology to eukaryotic DNA ligases that participate in DNA replication. Phylogenetic analysis of the sequences presented here is consistent with previous studies of DNA ligases (Nakatani et al. 2000). However, the addition of amino acid sequences for FaLig and related enzymes from other Thermoplasmatales identified that these are more similar to DNA ligases that have been characterized from Crenarchaeota (Jeon and Ishikawa, 2003; Kletzin 1992; Lai et al. 2002) compared each time-point, $10 \mu \mathrm{l}$ of sample was removed and the reaction stopped. All samples were analysed on a denaturing polyacrylamide gel. The marker contained a mixture of fluoresceinlabelled oligonucleotides of the specified size. b The extent of nick-joining was quantitated for T4Dnl (filled square, dashed line) and FaLig (open triangle, solid line)

to those from Euryarchaeota (Gunther et al. 2002; Keppetipola and Shuman 2005; Nakatani et al. 2000; Rolland et al. 2004; Sriskanda et al. 2000; Zhao et al. 2006). This phylogenetic description suggests that lateral gene transfer has occurred in the evolution of the DNA ligases of the Euryarchaeota. Detailed analysis of additional archaeal genome sequences will be required to resolve whether this observation is only associated with DNA ligases or whether additional genes have undergone such evolution.

The most significant result from this biochemical study is that optimal nick-joining by FaLig occurs at pH 6-7. Similar observations were made for an unusual type of DNA repair protein from $F$. acidarmanus Fer1 (Kanugula et al. 2005). These results suggest that at least some of the enzymes involved in DNA metabolism are optimized to function in the intracellular environment of this organism, which has been measured to be at pH 5.6 (Macalady et al. 2004). The situation may not be the same for all proteins, since a recent in vitro study suggests some intracellular or membrane-bound proteins of $F$. acidiphilum-a close relative of $F$. acidarmanus Fer1-have optimal activity in the $\mathrm{pH}$ range 2-4 (Golyshina et al. 2006). The precise explanation for the variations in observed $\mathrm{pH}$ optima in these different studies is unclear. It is possible that proteins experience different $\mathrm{pH}$ conditions 
Fig. 7 Substrate specificity of Ferroplasma acidarmanus DNA ligase. The nick-joining activity of $F$. acidarmanus Fer1 DNA ligase (FaLig) was tested on 20 bp doublestranded substrates containing differing fragments of DNA and RNA. a Schematic diagram of the substrates used in the ligation assay, with DNA and RNA being represented by filled and hatched boxes, respectively. b In vitro ligation assays performed in a total volume of $5 \mu \mathrm{l}(50 \mathrm{mM}$ Tris-acetate, $\mathrm{pH}$ 6.5, $10 \mathrm{mM}$ $\mathrm{MgCl}_{2}, 10 \mathrm{mM}$ DTT, $1 \mathrm{mM}$ ATP) for $18 \mathrm{~h}$ at $30^{\circ} \mathrm{C}$ with 0.66 pmol of FaLig and the various substrates (45 pmol). Samples were analysed on a denaturing polyacrylamide gel
A

\begin{tabular}{|c|c|}
\hline Name & Substrate $($ filled $=\mathrm{DNA}$; hatched $=$ RNA $)$ \\
\hline Substrate 1 & $\begin{array}{l}-3^{\prime}, \\
-5^{\prime},\end{array}$ \\
\hline Substrate 2 & 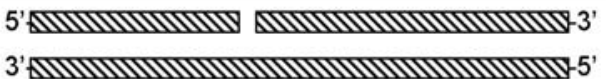 \\
\hline Substrate 3 & 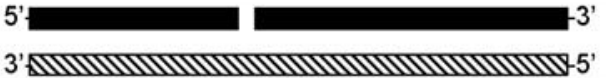 \\
\hline Substrate 4 & 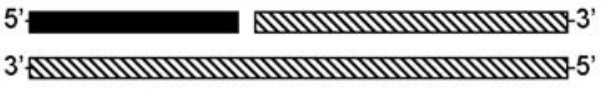 \\
\hline Substrate 5 & 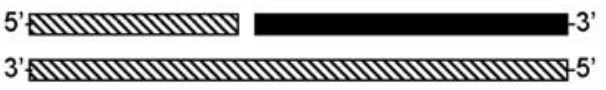 \\
\hline Substrate 6 & 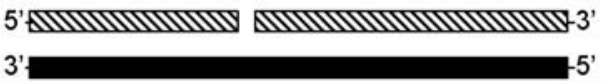 \\
\hline Substrate 7 & 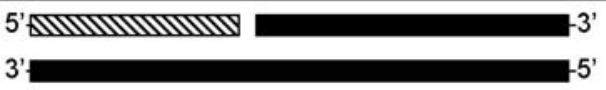 \\
\hline Substrate 8 & 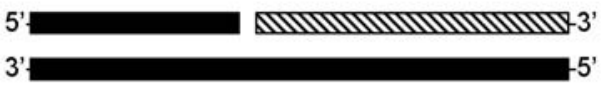 \\
\hline
\end{tabular}

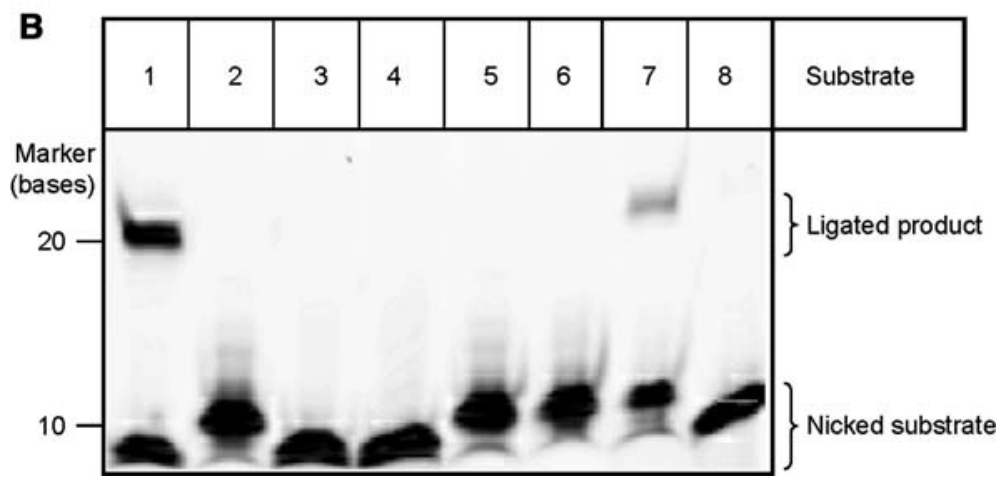

in $F$. acidiphilum and $F$. acidarmanus Fer1, but this seems unlikely given that all available evidence suggests that the organisms are extremely closely related. Perhaps more likely is that the differences are due to the studies of different types of enzymes and that this may indicate that different compartments within the organisms experience different $\mathrm{pH}$ (Golyshina et al. 2006). In this case, the pH optima of enzymes acting on DNA are closest to neutral (Kanugula et al. 2005), perhaps suggesting that the organisms have evolved mechanisms to protect their genome from harsh, acidic environments. A further explanation for the observations of different $\mathrm{pH}$ optima for proteins is that some of them may not be functioning at their optimal level within the cell. Further experimentation is required to identify whether these acidophilic organisms experience variation of $\mathrm{pH}$ within their cells or if some of the enzymes are not functioning at their optimal $\mathrm{pH}$.
The $\mathrm{pH}$ profile of FaLig is similar to that observed for a variety of DNA ligases, but it is now clear that the optimal $\mathrm{pH}$ for activity varies for enzymes from different organisms. In terms of archaea that grow at neutral $\mathrm{pH}$, the optimal activity of their DNA ligases has been detected to be $\mathrm{pH} 7-8.5$ (Jeon and Ishikawa 2003; Keppetipola and Shuman 2005; Rolland et al. 2004; Sriskanda et al. 2000). For DNA ligase from $S$. shibatae, which is able to grow at $\mathrm{pH} 2-4$, optimal nickjoining was detected at pH 6-7 (Lai et al. 2002). From these results it is tempting to speculate that those organisms that can grow in acidic environments have DNA ligases with $\mathrm{pH}$ optima that are more acidic. However, this is probably too simplistic, as indicated by the fact that there is a different $\mathrm{pH}$ optima for two nucleic acid ligases from bacteriophage T4, which will obviously experience the same cellular environment (Bullard and Bowater 2006). 
Analysis of the activity of FaLig in the presence of different co-factors identified optimal ligation with ATP, with a low-level of activity with dATP. Similar observations were made with the DNA ligase from Methanobacterium thermoautotrophicum (Sriskanda et al. 2000). Extensive ligation by FaLig was detected in the presence of $\mathrm{Mg}^{2+}$ or $\mathrm{Mn}^{2+}$, as observed with many other DNA ligases (Shuman and Lima 2004; Tomkinson et al. 2006). F. acidarmanus Fer1 can grow in the presence of high concentrations of a wide range of metals, but our in vitro experiments only detected nick-joining activity in the presence of $\mathrm{Mg}^{2+}$ or $\mathrm{Mn}^{2+}$. Further studies will be required to assess whether FaLig may be active in the presence of other cations under cellular conditions present within F. acidarmanus Fer1.

In summary, this study describes the cloning and characterization of the single DNA ligase encoded by the genome of $F$. acidarmanus Fer1. In providing this characterization of a DNA ligase from an extreme acidophile, knowledge of these essential proteins is extended to another phylogenetic family.

Acknowledgments We thank Des Bullard and Heather Sayer for assistance with experiments and discussions about the project. This work was funded by the BBSRC and Society for General Microbiology.

\section{References}

Bullard DR, Bowater RP (2006) Direct comparison of nickjoining activity of the nucleic acid ligases from bacteriophage T4. Biochem J 398:135-144

Castanie MP, Berges H, Oreglia J, Prere MF, Fayet O (1997) A set of pBR322-compatible plasmids allowing the testing of chaperone-assisted folding of proteins overexpressed in Escherichia coli. Anal Biochem 254:150-152

Chen Y, Song J, Sui SF, Wang DN (2003) DnaK and DnaJ facilitated the folding process and reduced inclusion body formation of magnesium transporter CorA overexpressed in Escherichia coli. Protein Expr Purif 32:221-231

Darland G, Brock TD, Samsonoff W, Conti SF (1970) A thermophilic, acidophilic mycoplasma isolated from a coal refuse pile. Science 170:1416-1418

Dermody JJ, Robinson GT, Sternglanz R (1979) Conditionallethal deoxyribonucleic acid ligase mutant of Escherichia coli. J Bacteriol 139:701-704

Doherty AJ, Suh SW (2000) Structural and mechanistic conservation in DNA ligases. Nucleic Acids Res 28:4051-4058

Dopson M, Baker-Austin C, Hind A, Bowman JP, Bond PL (2004) Characterization of Ferroplasma isolates and Ferroplasma acidarmanus sp. nov., extreme acidophiles from acid mine drainage and industrial bioleaching environments. Appl Environ Microbiol 70:2079-2088

Edwards KJ, Bond PL, Gihring TM, Banfield JF (2000) An archaeal iron-oxidizing extreme acidophile important in acid mine drainage. Science 287:1796-1799
Finn RD, Mistry J, Schuster-Bockler B, Griffiths-Jones S, Hollich V, Lassmann T, Moxon S, Marshall M, Khanna A, Durbin R, Eddy SR, Sonnhammer ELL, Bateman A (2006) Pfam: clans, web tools and services. Nucleic Acids Res 34:D247-D251

Futterer O, Angelov A, Liesegang H, Gottschalk G, Schepers B, Dock C, Antranikian G, Liebl W (2004) Genome sequence of Picrophilus torridus and its implications for life around pH 0. Proc Natl Acad Sci USA 101:9091-9096

Goenka S, Rao CM (2001) Expression of recombinant zetacrystallin in Escherichia coli with the help of GroEL/ES and its purification. Protein Exp Purif 21:260-267

Golyshina OV, Golyshin PN, Timmis KN, Ferrer M (2006) The 'pH optimum anomaly' of intracellular enzymes of Ferroplasma acidiphilum. Environ Microbiol 8:416-425

Golyshina OV, Timmis KN (2005) Ferroplasma and relatives, recently discovered cell wall-lacking archaea making a living in extremely acid, heavy metal-rich environments. Environ Microbiol 7:1277-1288

Gunther S, Montes M, de DA, del VM, Atencia EA, Sillero A (2002) Thermostable Pyrococcus furiosus DNA ligase catalyzes the synthesis of (di)nucleoside polyphosphates. Extremophiles 6:45-50

Ho CK, Shuman S (2002) Bacteriophage T4 RNA ligase 2 (gp24.1) exemplifies a family of RNA ligases found in all phylogenetic domains. Proc Natl Acad Sci USA 99:1270912714

Ho CK, Wang LK, Lima CD, Shuman S (2004) Structure and mechanism of RNA ligase. Struct (Camb) 12:327-339

Jeon SJ, Ishikawa K (2003) A novel ADP-dependent DNA ligase from Aeropyrum pernix K1. FEBS Lett 550:69-73

Kanugula S, Pauly GT, Moschel RC, Pegg AE (2005) A bifunctional DNA repair protein from Ferroplasma acidarmanus exhibits O6-alkylguanine-DNA alkyltransferase and endonuclease V activities. Proc Natl Acad Sci USA 102:3617-3622

Kelman Z, White MF (2005) Archaeal DNA replication and repair. Curr Opin Microbiol 8:669-676

Keppetipola N, Shuman S (2005) Characterization of a thermophilic ATP-dependent DNA ligase from the euryarchaeon Pyrococcus horikoshii. J Bacteriol 187:6902-6908

Kletzin A (1992) Molecular characterisation of a DNA ligase gene of the extremely thermophilic archaeon Desulfurolobus ambivalens shows close phylogenetic relationship to eukaryotic ligases. Nucleic Acids Res 20:5389-5396

Kodama KI, Barnes DE, Lindahl T (1991) In vitro mutagenesis and functional expression in Escherichia coli of a cDNA encoding the catalytic domain of human DNA ligase I. Nucleic Acids Res 19:6093-6099

Lai X, Shao H, Hao F, Huang L (2002) Biochemical characterization of an ATP-dependent DNA ligase from the hyperthermophilic crenarchaeon Sulfolobus shibatae. Extremophiles 6:469-477

Lavesa-Curto M, Sayer H, Bullard D, MacDonald A, Wilkinson A, Smith A, Bowater L, Hemmings A, Bowater R (2004) Characterisation of a temperature-sensitive DNA ligase from Escherichia coli. Microbiology 150:4171-4180

Lehman IR (1974) DNA ligase: structure, mechanism, and function. Science 186:790-797

Ludwig W, Strunk O, Westram R, Richter L, Meier H, Yadhukumar, Buchner A, Lai T, Steppi S, Jobb G, Forster W, Brettske I, Gerber S, Ginhart AW, Gross O, Grumann S, Hermann S, Jost R, Konig A, Liss T, Lussmann R, May M, Nonhoff B, Reichel B, Strehlow R, Stamatakis A, Stuckmann N, Vilbig A, Lenke M, Ludwig T, Bode A, Schleifer 
KH (2004) ARB: a software environment for sequence data. Nucleic Acids Res 32:1363-1371

Macalady JL, Vestling MM, Baumler D, Boekelheide N, Kaspar CW, Banfield JF (2004) Tetraether-linked membrane monolayers in Ferroplasma spp: a key to survival in acid. Extremophiles 8:411-419

Makarova KS, Koonin EV (2003) Comparative genomics of Archaea: how much have we learned in six years, and what's next? Genome Biol 4:115

Makarova KS, Koonin EV (2005) Evolutionary and functional genomics of the Archaea. Curr Opin Microbiol 8:586-594

Marchler-Bauer A, Anderson JB, Cherukuri PF, DeWeese-Scott C, Geer LY, Gwadz M, He S, Hurwitz DI, Jackson JD, Ke Z, Lanczycki CJ, Liebert CA, Liu C, Lu F, Marchler GH, Mullokandov M, Shoemaker BA, Simonyan V, Song JS, Thiessen PA, Yamashita RA, Yin JJ, Zhang D, Bryant SH (2005) CDD: a conserved domain database for protein classification. Nucleic Acids Res 33:D192-D196

Martins A, Shuman S (2004) An RNA Ligase from Deinococcus radiodurans. J Biol Chem 279:50654-50661

Nakatani M, Ezaki S, Atomi H, Imanaka T (2000) A DNA ligase from a hyperthermophilic archaeon with unique cofactor specificity. J Bacteriol 182:6424-6433

Nandakumar J, Ho CK, Lima CD, Shuman S (2004) RNA substrate specificity and structure-guided mutational analysis of bacteriophage T4 RNA ligase 2. J Biol Chem 279:31337-31347

Nandakumar J, Shuman S (2004) How an RNA ligase discriminates RNA versus DNA damage. Mol Cell 16:211-221

Nandakumar J, Shuman S (2005) Dual mechanisms whereby a broken RNA end assists the catalysis of its repair by T4 RNA ligase 2. J Biol Chem 280:23484-23489

Pascal JM, O'Brien PJ, Tomkinson AE, Ellenberger T (2004) Human DNA ligase I completely encircles and partially unwinds nicked DNA. Nature 432:473-478

Rolland JL, Gueguen Y, Persillon C, Masson JM, Dietrich J (2004) Characterization of a thermophilic DNA ligase from the archaeon Thermococcus fumicolans. FEMS Microbiol Lett 236:267-273

Ruepp A, Graml W, Santos-Martinez ML, Koretke KK, Volker C, Mewes HW, Frishman D, Stocker S, Lupas AN, Baumeister W (2000) The genome sequence of the thermoacidophilic scavenger Thermoplasma acidophilum. Nature 407:508-513

Sambrook J, Russell D (2001) Molecular cloning: a laboratory manual. Cold Spring Harbor Laboratory Press, Cold Spring Harbor

Schleper C, Jurgens G, Jonuscheit M (2005) Genomic studies of uncultivated archaea. Nat Rev Micro 3:479-488

Searcy DG (1976) Thermoplasma acidophilum: intracellular $\mathrm{pH}$ and potassium concentration. Biochim Biophys Acta 451:278-286
Sekiguchi J, Shuman S (1997) Ligation of RNA-containing duplexes by vaccinia DNA ligase. Biochemistry 36:9073-9079

She Q, Singh RK, Confalonieri F, Zivanovic Y, Allard G, Awayez MJ, Chan-Weiher CC, Clausen IG, Curtis BA, De Moors A, Erauso G, Fletcher C, Gordon PM, Heikamp-de Jong I, Jeffries AC, Kozera CJ, Medina N, Peng X, ThiNgoc HP, Redder P, Schenk ME, Theriault C, Tolstrup N, Charlebois RL, Doolittle WF, Duguet M, Gaasterland T, Garrett RA, Ragan MA, Sensen CW, Van der Oost J (2001) The complete genome of the crenarchaeon Sulfolobus solfataricus P2. Proc Natl Acad Sci USA 98:7835-7840

Shuman S, Lima CD (2004) The polynucleotide ligase and RNA capping enzyme superfamily of covalent nucleotidyltransferases. Curr Opin Struct Biol 14:757-764

Sriskanda V, Kelman Z, Hurwitz J, Shuman S (2000) Characterisation of an ATP-dependent DNA ligase from the thermophilic archaeon Methanobacterium thermoautotrophicum. Nucleic Acids Res 28:2221-2228

Sriskanda V, Shuman S (1998) Specificity and fidelity of strand joining by Chlorella virus DNA ligase. Nucleic Acids Res 26:3536-3541

Timson DJ, Singleton MR, Wigley DB (2000) DNA ligases in the repair and replication of DNA. Mutat Res 460:301-318

Tomkinson AE, Vijayakumar S, Pascal JM, Ellenberger T (2006) DNA ligases: structure, reaction mechanism, and function. Chem Rev 106:687-699

Tyson GW, Chapman J, Hugenholtz P, Allen EE, Ram RJ, Richardson PM, Solovyev VV, Rubin EM, Rokhsar DS, Banfield JF (2004) Community structure and metabolism through reconstruction of microbial genomes from the environment. Nature 428:37-43

White MF (2003) Archaeal DNA repair: paradigms and puzzles. Biochem Soc Trans 31:690-693

Wilkinson A, Day J, Bowater R (2001) Bacterial DNA ligases. Mol Microbiol 40:1241-1248

Wilkinson A, Sayer H, Bullard D, Smith A, Day J, Kieser T, Bowater R (2003) NAD+-dependent DNA ligases of Mycobacterium tuberculosis and Streptomyces coelicolor. Proteins Struct Funct Genet 51:321-326

Wilkinson A, Smith A, Bullard D, Lavesa-Curto M, Sayer H, Bonner A, Hemmings AM, Bowater R (2005) Analysis of ligation and DNA binding by Escherichia coli DNA ligase (LigA). Biochim Biophys Acta 1749:113-122

Yin S, Ho CK, Shuman S (2003) Structure-function analysis of T4 RNA ligase 2. J Biol Chem 278:17601-17608

Yin S, Kiong Ho C, Miller ES, Shuman S (2004) Characterization of bacteriophage KVP40 and T4 RNA ligase 2. Virology 319:141-151

Zhao A, Gray FC, MacNeill SA (2006) ATP- and NAD+dependent DNA ligases share an essential function in the halophilic archaeon Haloferax volcanii. Mol Microbiol 59:743-752 